\title{
The role of tax incentives in encouraging energy efficiency in the largest listed South African businesses
}

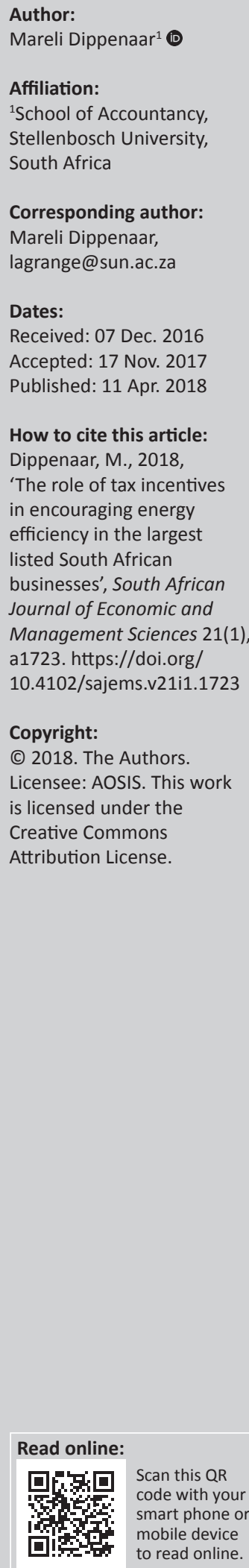

Background: South Africa is faced with a significant challenge of securing the supply of electricity as well as reducing its greenhouse gas emissions. The implementation of energy efficiency (EE) and renewable energy (RE) measures by energy consumers, especially businesses, is becoming increasingly important and a number of tax incentives have been introduced to promote EE and RE.

Objective: The objective of this preliminary study was to determine the role that the available tax incentives play in the decision making of South African businesses regarding investment in RE or EE projects.

Aim: To determine this role, the largest South African businesses were selected from the Johannesburg Stock Exchange Top 40 Index.

Method: The study contained both empirical and non-empirical elements. A literature review was conducted to determine the role of tax incentives globally, while questionnaires were distributed to determine the role in South Africa.

Results: Findings highlighted that, while tax incentives do play a role in decision making, various other non-tax factors drive South African businesses' decisions to invest in EE and/or RE projects. These businesses do not perceive the available tax incentives as effective, nor do they regard them as sufficiently motivating for businesses to change their environmental behaviour. They also feel that the government should reduce the burden of complying with the requirements of Section 12L (the EE allowance).

Conclusion: Improving the available RE and EE tax incentives in South Africa might result in more businesses considering the implementation of RE or EE projects. It is therefore recommended that the available tax incentives are expanded and/or the qualifying criteria simplified.

\section{Introduction}

South Africa is faced with a significant challenge of securing the supply of electricity, since the demand for electricity continues to grow within a supply-constrained environment. In addition to this challenge, South Africa faces the challenge of reducing its greenhouse gas (GHG) emissions, which directly contribute to climate change. The country ranks among the top 20 global emitters of GHGs and carbon dioxide $\left(\mathrm{CO}_{2}\right)$ and is the largest emitter in Africa, largely because of its energy sector. South Africa has an energy intensive economy. Coal provides for approximately $65 \%$ of the country's primary energy needs and it is likely to provide the majority of the country's primary energy for the next few decades, as it is a financially attractive and abundant source of energy (PBL 2016; Republic of South Africa 2015a). More specifically, coal is used to generate approximately $91 \%$ of the electricity in South Africa (Eskom 2016). Coal combustion mainly results in $\mathrm{CO}_{2}$ emissions, which is the main GHG that has been linked to climate change, in South Africa (Cohen \& Winkler 2014; Republic of South Africa 2004).

The government of South Africa is establishing and growing a renewable energy (RE) industry, in line with its Integrated Resource Plan, through the Independent Power Producer Procurement Programme, in order to substantially reduce the country's $\mathrm{CO}_{2}$ emissions, to secure electricity supply and to diversify the country's energy sources (IPP Projects n.d.; Republic of South Africa 2010). In addition, the South African government has implemented measures to promote energy efficiency (EE), including the 2005 National EE Strategy, the National EE Action Plan of 2012, the EE Target Monitoring System of 2014 and the post-2015 National EE Strategy of which the first draft was issued for comment toward the end of 2016 (Republic of South Africa 2016c). The South African government recognises the country's role in the global efforts to reduce GHG emissions 
and has ratified the Paris Agreement on Climate Change at the 21st session of the Conference of the Parties to the United Nations Framework Convention on Climate Change (Republic of South Africa 2016b).

Market mechanisms, such as market-based instruments (MBIs), are increasingly used by governments to promote environmentally friendly behaviour. Such instruments are no longer used only by developed countries, but are also increasingly being implemented by developing countries (Economy 2006, cited in Nteo 2012). As a result of all the environmental challenges faced globally, attention has been shifted away from government regulations for environmental governance to the use of market mechanisms (Economy 2006). Some MBIs use existing markets and aim to internalise unpriced environmental costs and benefits by incorporating them into price structures. Examples of such instruments include fiscal measures, such as subsidies, tax instruments and user charges (Republic of South Africa 2006).

There are various valid reasons for applying a combination of instruments, instead of only relying on a single instrument to address a given environmental problem. One such reason is that most environmental problems have 'multiple aspects' that need to be addressed. Often the effectiveness and efficiency of both instruments are enhanced when two instruments are combined (Braathen 2007). According to Braathen (2007), the ideal situation is one where everyone that contributes to a given environmental problem should have an economic incentive to alter their behaviour to become more environmentally friendly. He found that, in many of the cases that he examined, significantly higher environmental effectiveness could be achieved if economic incentives to reduce emissions had been granted to key categories of polluters.

The key to successful government intervention is to plan and design the appropriate policies thoroughly prior to implementation (Geller et al. 2006). Fiscal or financial incentives (which include tax incentives) are some of the most common government instruments that have proven to be effective in promoting a transition to a greener economy (KPMG 2013a). Tax incentives have successfully encouraged EE in the Netherlands (Lomas 2012) and, when combined with other instruments, they can also encourage RE (Centre for Resource Solutions [CRS] 2005). In addition, tax incentives also have the potential to encourage investment in research and development (R\&D) of technologies for electricity generation and use that limit emissions, such as RE and EE technologies (KPMG 2013b).

It is not clear whether the tax incentives currently available in South Africa are effective in terms of changing behaviour regarding energy use and whether they provide a sufficient financial incentive for businesses to invest in RE or EE. Consequently, the objective of this preliminary study is to determine the effectiveness of the currently available tax incentives in South Africa in changing the environmental behaviour of businesses, by determining the role that the currently available tax incentives play in the decision making of South African businesses regarding investment in RE or EE projects (even if through $R \& D$ ). The findings are considered relevant to policymakers, as these could potentially highlight areas for consideration for improvement, as well as for businesses, as they highlight the tax incentives that are potentially available for them to utilise.

\section{Methods Study design}

The study contains both empirical and non-empirical elements and the following primary research questions are investigated:

1. Are tax incentives used globally to effect change in energy consumers' environmental behaviour, specifically regarding investment in RE and EE projects (even if through $R \& D)$, and is it an effective measure?

2. Are tax incentives used in South Africa to effect change in businesses' environmental behaviour, specifically regarding investment in RE and EE projects (even if through $R \& D)$, and is it an effective measure?

The second research question was addressed by investigating the following questions:

2.1. What are the available tax instruments in South Africa that can potentially stimulate investment in $\mathrm{RE}$, or $\mathrm{EE}$ projects (even if through $R \& D$ )?

2.2. Do businesses utilise the available EE and RE tax incentives?

2.3. How important is the existence of tax incentives to businesses in deciding to invest in RE or EE projects?

2.4. What factors drive the decision making of businesses regarding investment in RE or EE projects?

2.5. Are the available tax incentives in South Africa effective in changing behaviour and stimulating investment in RE or EE projects?

The method used to investigate the first research question was non-empirical, in the form of a literature review. The second research question was investigated by the use of questionnaires (i.e., empirical).

\section{Study population and sampling strategy}

The companies were selected from the Johannesburg Stock Exchange (JSE) Top 40 Index (JSE Top 40), an index whereby the constituents of the All Share Index are ranked by market capitalisation, as at 29 May 2015 (Mychajluk 2015). For the selection, the JSE Top 40 companies registered in South Africa were identified. In the case of a dual-listed company structure where the company included in the JSE Top 40 is a holding company not registered in South Africa, the related holding company that is registered in South Africa, if any, was selected as part of the study. An example of such a structure is the Mondi Group. In terms of a dual-listed company sharing arrangement, Mondi Plc and Mondi Ltd agreed contractually to operate and manage their businesses as if it 
were a single economic entity, while retaining their separate legal identity and existing stock exchange listings. Mondi Ltd has a primary listing on the JSE Ltd, while Mondi Plc has a premium listing on the London stock exchange and a secondary listing on the JSE Ltd. Mondi Plc was selected for the study from the JSE Top 40 but, since it is registered in the UK, the questionnaire was sent to Mondi Ltd. This brought the total number of companies initially selected for the survey to 28 .

A representative of each company was requested to complete the questionnaire in respect of the South African group as a whole, where possible (in other words, representing the South African holding company included in the JSE Top 40 and all its South African subsidiaries). If this was not possible, possibly because the group is so diverse and consists of too many companies, each with different EE and RE practices, they were requested to complete the form for the holding company only (i.e., the entity included in the JSE Top 40), as long as the holding company is an operating company and not merely an investment holding company. Lastly, if neither of these could be done, the respondent was requested to identify the company's South African subsidiary with the largest energy usage and complete the survey in respect of that entity only. One of the 28 companies initially selected is merely an investment holding company and has no subsidiaries, therefore it was excluded from the study. Another company was also excluded, based on the fact that it operates in a decentralised environment and covers a host of industries and therefore the majority of the questions would be specific to the individual businesses. This group is also not energy intensive and the company with the largest energy usage is completely insignificant from a group context. A final number of 26 companies was therefore included in the study, and these received questionnaires. A list of these companies, together with the sectors that they operate in, is provided in Appendix 1.

The reason for selecting the population from the JSE Top 40 is that it is likely that these companies would have invested in $\mathrm{EE}$ or RE and therefore that the questionnaire would be relevant to them. It is expected that investment in EE or RE would be important to these companies, since sustainability, which includes environmental aspects such as EE and/or RE, inter alia, is a core governance issue. The King Code on Corporate Governance for South Africa (the King Code) recommends integrated sustainability performance and integrated reporting and it is recommended that the integrated report have sufficient information regarding environmental, social and governance issues (Institute of Directors Southern Africa 2009). Although companies listed on the JSE are not required to comply with chapter nine of the King Code, which deals with integrated reporting and disclosure, it still needs to be applied by such companies on an 'apply or explain' basis (JSE 2013). In addition, high costs are associated with investment in EE and RE and it is expected that these large companies included in the JSE Top 40 would have the necessary resources or access thereto.
A total number of 22 of the 26 companies in the population (and 30 of the JSE Top 40 companies) are also included in the JSE's most recent Socially Responsible Index (SRI) as at 27 November 2014 (JSE 2014a). This further strengthens the expectation that these entities would have made some investment in EE or RE, since this index identifies those companies listed on the All Share Index that meet certain environmental, social, governance and related sustainability criteria (JSE 2014b).

All of the respondents (100\%) indicated that they either have completed EE projects or that they are in the process of implementing EE measures, while 10 of the respondents $(63 \%)$ are generating their own renewable electricity, even if only on a small scale, and two others are either planning it for the future or still researching economically viable options to do so. Ten respondents also indicated that their businesses are performing $R \& D$ activities relating to $E E$ or $R E$. This offers a strong measure of confidence about the relevance of the survey to the selected population.

\section{Development of questionnaires}

The questionnaires were developed based on an understanding gained from performing a literature review. Some questions were formulated based on questions and wording used by Du Plooy (2012), as well as an international survey performed by PricewaterhouseCoopers (2010) to ensure that the questions are clear, unambiguous and appropriate for this study. Du Plooy conducted a study of South African vehicle manufacturers to investigate the possible implementation of a 'feebate' policy to reduce $\mathrm{CO}_{2}$ emissions and to determine if the current tax incentives available to South African vehicle manufacturers to invest in reducing $\mathrm{CO}_{2}$ emissions are utilised by them. As part of the PricewaterhouseCoopers study, almost 700 global executives of 15 countries were interviewed during the period September to November 2009, to determine their perspectives regarding the impact of climate change, the government's role in protecting the environment and which environmental policy tools they prefer, inter alia.

The questionnaire that was issued covered the following broad areas, in order to address research questions 2.2-2.5:

- Understanding businesses' current and planned RE or EE projects, including whether or not they utilise the currently available EE and RE tax incentives.

- The importance of tax incentives to businesses in RE- or EE-related decision making.

- Which factors (tax or non-tax) drive the decision making regarding investment in RE or EE projects.

- The effectiveness of the available tax incentives in altering environmental behaviour by promoting investment in RE or EE projects.

\section{Administration and response rate}

The link to the electronic questionnaire, which was set up using SUrveys (a web-based survey program), was e-mailed to a representative of each of the companies selected for the 
study. Their contact details were obtained either directly from the companies' websites or from phoning or e-mailing the company. A total number of 26 questionnaires were sent out, of which 16 responses were received by the cut-off date. This represents a response rate of $62 \%$. Although this appears to be a relatively small sample from an already small population, statistical differences could still be detected using ordinal data. The questionnaires were completed either by a senior representative in finance, tax or sustainability, mostly in consultation with one another where there was uncertainty about answering certain aspects.

\section{Data analysis}

The data from the completed questionnaires was analysed statistically using Statistica 10.0 (StatSoft Inc.). To measure if, for a particular Yes/No question, the number of Yes's reported is significantly more than the number of No's (or vice versa), a conclusion is reached with a significance level of $5 \%$, if the probability $(p)$ of exceeding the observed number $(x)$ of Yes's, assuming that there is no difference between Yes and No (i.e., actually $50 \%$ ), is less than $5 \%$. Consequently, whenever $x=11$ or more from the $n=16$ respondents, it was referred to as a statistically significant proportion of respondents. This number was determined using the binomial distribution, which is typically used to test for significance in qualitative data with only two options (i.e., Yes/No answers).

The results from the questionnaires are meant to provide insights for policymakers, rather than to recommend a specific incentive. Since the percentages in the tables are rounded to integers, the sum of these proportions does not necessarily add up to precisely $100 \%$.

\section{Limitation}

Only normal tax incentives available in South Africa that can potentially stimulate investment in RE or EE, were considered. The relatively small population of 26 potential respondents is regarded as the most significant limitation of the study and generalisations cannot be made for all businesses in South Africa. However, this is only a preliminary study to determine the opinions of the largest market players in South Africa, who have taken RE and/or EE measures. Consequently, any conclusions drawn in this study may not reflect the views of all South African businesses that have implemented significant EE and/or RE measures, which are not expected to be many. Regardless of the apparent small number of observations, statistical differences could still be identified using ordinal data, but not for nominal data.

\section{The global use of and effectiveness of tax incentives in changing environmental behaviour Use of and effectiveness of tax incentives in general}

There are varied opinions about the effectiveness of tax incentives in successfully addressing environmental challenges and changing consumer behaviour. However, tax incentives are still widely used, both in developing and developed countries. Ashiabor (2005) found that economic instruments, for example, fiscal incentives, can be useful in constraining pollution, if applied correctly. He also found that positive fiscal policy instruments, such as tax incentives, tax subsidies, tax credits and grants, have been the primary instruments for addressing the issues of fuel security and environmental protection since the 1970s (Ashiabor 2005).

Certain researchers regard tax incentives as effective, but only when used in combination with other instruments (CRS 2005). Other economists and researchers argue that tax incentives are generally redundant and ineffective when attempting to stimulate investment (Bird 2008). The benefits of investment tax incentives are often overstated, while the costs are often underrated or completely overlooked (NathanMSI Group 2004). Incentives focused on investment may be successful, but too often problems arise, inter alia, as a result of competing policies, substitutability between capital and other inputs, impact of long term incentives and competition from other countries. These problems can mitigate or exacerbate the impact of incentives (Calitz, Wallace \& Burrows 2013). Tax incentives might be justified; however, it is important to remember that many other factors, including other economic, non-economic and social policy considerations, drive investment decisions (Calitz et al. 2013). There is empirical evidence on the effectiveness of tax incentives, but a country's overall economic characteristics may play a more important role than tax incentives (Zee, Stotsky \& Ley 2002). The Nathan-MSI Group (2004) agrees that tax can affect investments, but that non-tax considerations are far more important in determining most investment decisions. Nevertheless, tax incentives are still widely used and continue to play a significant role in the tax policies of both developing and developed countries, despite varied opinions and inconclusive evidence about the use and effectiveness thereof (Calitz et al. 2013; Nathan-MSI Group 2004; Zee et al. 2002). Although some believe that tax incentives distort investment decisions and are often ineffective, inefficient and prone to abuse and corruption (Easson \& Zolt 2002), tax incentives are likely to remain part of development policies globally (Calitz et al. 2013).

There is no standard recipe or blueprint government approach that will effectively create a green economy and a combination of policy instruments, which might include tax incentives, is often required in order to reduce emissions (Bierbaum \& Friedman 1992; Nteo 2012; Republic of South Africa 2006). Studies have indicated that it is likely that a combination of policy instruments is the most effective in realising the largest environmental and economic benefits (Winkler 2005). A combination of complementary policies, including tax incentives, was used with success in Denmark to encourage the development of its wind energy industry (Wiser, Hamrin \& Wingate 2002). According to Nteo (2012), an array of country-specific characteristics must be considered and governments should establish a combination of instruments that is appropriate for their circumstances. 
Having discussed the global use of and effectiveness of tax incentives in general, the following sections explore the global use of and effectiveness of tax incentives that target $\mathrm{EE}, \mathrm{RE}$ and R\&D, respectively.

\section{Use of and effectiveness of tax incentives that target energy efficiency}

According to Niesing (2012), EE begins with a change in human behaviour and EE and demand-side management are significantly affected by government interventions, such as incentives. He believes that EE may have the largest positive effect in reducing the emissions in the world in the short term. Furthermore, he points out that EE presents the lowest emission reduction cost option and presents financial benefits within a relatively short payback period. The European Commission also agrees that increased EE is the most cost-effective and swift way to reduce $\mathrm{CO}_{2}$ emissions (Markandya et al. 2009).

Both tax incentives and disincentives are used by governments all over the world to address environmental challenges, when aiming to reduce $\mathrm{CO}_{2}$ emissions and promote $\mathrm{EE}$ (KPMG 2013b). KPMG (2013b) found that the use of tax incentives and disincentives varies widely since each country is unique in the way that it manages its policy response to climate change and the reduction of $\mathrm{CO}_{2}$ emissions. However, governments across the globe seem to be making increased use of both incentives and disincentives (Chanel 2012).

MBIs, in the form of environmentally-related taxes and charges (disincentives), may address certain environmental concerns more efficiently than traditional regulatory approaches (Republic of South Africa 2006). According to Cargill (2011), the use of MBIs, which can include tax incentives and/or disincentives, is perhaps the most costeffective manner to achieve environmental goals. Bierbaum and Friedman (1992) agree that market-based approaches, such as carbon taxes or marketable permits, can be effective in lowering emissions in the electric utilities sector, but point out that government regulations, such as limits on allowable emissions and EE standards, could also be effective in lowering emissions. In order to operate effectively, MBIs, for example subsidies and taxes, require some form of regulatory measures, monitoring and enforcement (Republic of South Africa 2006). Bierbaum and Friedman (1992) and the Department of National Treasury (Republic of South Africa 2013) point out that a combination of regulatory and marketbased policies is required to prevent global warming. In a United States study by Yuan et al. (2011), it was found that a carbon tax would be the most cost-effective tool for lowering $\mathrm{CO}_{2}$ emissions and that an energy tax would be the most costeffective instrument to lower total energy consumption.

Developed and developing countries, however, have very different approaches when it comes to tax disincentives on non-renewable energy sources. KPMG studied 21 major economies of the world to establish which tax instruments are used in the area of environmental policies (KPMG 2013b). Only the developed countries in its study make use of such penalties. Developing economies appear to avoid using such tax penalties, presumably on the basis that such penalties could damage development and growth prospects (KPMG 2013b). Anjum (2008) agrees that environmental taxes (disincentives) are not necessarily practical for developing countries, as they can affect a country's competitiveness. There are, however, various measures that can be taken to reduce the impact on a country's competitiveness. Van Schalkwyk (2012) also found that incentives to promote environmentally friendly behaviour are preferred to disincentives in developing countries. However, environmental tax disincentives can be effective in fighting climate change as they can lead to decreased pollution. In the long term, the circumstances of societies will improve and global warming will be reduced (Anjum 2008). The perception exists that incentives, such as tax subsidies, tax credits and grants, have a much greater impact on consumer behaviour than taxes (disincentives), since they are perceived as a reward, while taxes are seen as punishment. There is, in fact, empirical evidence that incentives are generally more effective in swaying customers toward RE and EE than environmental taxes (Bennet \& Moore 1981).

According to Niesing (2012), government regulations alone are not enough to reduce demand for energy, and energy prices and incentives have a significant role to play. It has been demonstrated in a variety of contexts that investment, tax credits are powerful instruments for inducing investment and Hassett and Metcalf (1995) have found that tax incentives increase the probability of investing in EE capital. They also found that consumers (individuals) respond in a rational way to energy-conservation incentives. According to Zhou, Levine and Price (2010), the use of tax and fiscal policies, such as taxes on energy consumption, tax rebates for EE and tax credits for investment in EE measures, inter alia, have been found to be effective instruments to encourage EE in certain countries. It is difficult to conclude on the effectiveness of tax instruments in achieving EE since evidence is sparse (KPMG 2013b), although one example of the success thereof is the Dutch energy investment allowance scheme that contributed to the country's increased business investment in EE in 2012 (Lomas 2012).

It is becoming more common for governments all over the world to adopt policies that combine RE and EE. EE is often the preferred approach as an inexpensive and easy way of addressing the challenges of limited supply of electricity and climate change, as opposed to building new renewable electricity plants. The majority of the countries studied by KPMG use tax incentives to encourage EE in business (KPMG 2013b). It is, however, not sufficient to target EE in isolation. In the long term, it is important to also target the electricity supply side and RE (Winkler 2007).

\section{Use of and effectiveness of tax incentives that target renewable energy}

As is evident worldwide, economic instruments, such as environmental taxes, fiscal incentives, market instruments and other direct regulatory measures, can be used to increase 
RE generation (Ashiabor 2005). The major driver of the strong growth in the global RE industry is government incentives, including credits, grants, tax holidays, accelerated depreciation allowances and other non-tax incentives. Disincentives in the form of, inter alia, taxes and penalties, such as carbon taxes, cap and trade schemes and energy taxes, are also used by governments to reduce emissions (KPMG 2013a). KPMG performed a study among 28 countries to determine the tax instruments and other incentives used by governments to promote an RE industry. Regulatory policies, fiscal incentives and public financing were used by the countries studied. Fiscal incentives include grants, subsidies or rebates, as well as certain tax incentives (KPMG 2013a). Deloitte (2010) found, similarly to KPMG (2013a), that a broad range of incentives are used globally to promote RE. The incentives used vary from market mechanisms, like carbon credits and renewable obligation certificates, to feedin tariffs and tax incentives, such as production tax credits. All these instruments have different complexities, strengths and weaknesses (Deloitte 2010). Even within individual countries, a combination of mechanisms is often used and many of these mechanisms co-exist.

The World Energy Council (2010) and the Department of Minerals and Energy (Republic of South Africa 2004) state that government intervention, in the form of financial incentives, can be used to promote an RE industry. According to Zhou, Wang and McCalley (2011), a policy is said to be effective when it can stimulate increased investment in RE (by improving the cost competitiveness of RE in the short term) and accelerate RE technology development in the long run. The use of fiscal incentives is one type of government approach that is proven to be effective in promoting an RE industry (KPMG 2013a). According to KPMG (2013b), governments of both developed and developing countries are most active in using tax incentives in the RE policy area, as opposed to the other eight environmental policy areas identified by KPMG, which include EE, inter alia. The CRS (2005) examined a number of countries worldwide to learn from their tax incentive policies to promote RE and concluded that tax incentives are effective, powerful and highly flexible instruments to promote RE industries. The World Resources Institute (2008) and the Intergovernmental Panel on Climate Change (IPCC) agree that certain tax instruments are effective. According to the IPCC (2007, cited in Nortje 2009), carbon taxes and tax incentives for the production, consumption and R\&D of RE, inter alia, are effective tax instruments to address the challenges of climate change. The United Nations Industrial Development Organisation (UNIDO 2009) agrees that tax incentives are potentially effective as they found that tax credits, inter alia, have been used successfully to promote RE in developing countries. Tax incentives in isolation are, however, not the most effective instruments to promote an RE industry (CRS 2005) and, since it is unlikely that one financial incentive on its own will be sufficient, a combination of incentives that complement one another can play a significant role (Gouchoe, Everette \& Heynes 2002).

\section{Use of and effectiveness of tax incentives that target research and development}

Tax incentives aimed at encouraging $R \& D$ have the potential to encourage R\&D of RE and EE technologies, which could, in turn, contribute to the reduction of emissions from electricity generation. KPMG found that 18 of the 21 countries studied, use their tax systems to promote R\&D. This is because innovation is critical to governments' environmental policy goals. R\&D drives down the cost of technologies, improves the business case for private sector investment, reduces costs to governments and enables solutions to be delivered at scale (KPMG 2013b).

In his analysis of the research performed by others, Sawyer (2005) found that incentives in the form of additional tax credits will generally be cost-effective and result in higher R\&D expenditure levels. Similarly, the IPCC (2007, cited in Nortje 2009) determined that climate change can be addressed effectively by tax incentives for the R\&D of RE, inter alia.

\section{Conclusion: the global situation}

Literature suggests that tax incentives could effectively address environmental challenges and change consumer behaviour, although tax incentives are generally more effective in combination with other policy instruments. Some argue, however, that tax incentives are ineffective, because non-tax considerations have a larger impact on investment decisions and many factors besides tax incentives or disincentives drive investment decisions. Empirical evidence on the cost effectiveness of tax incentives also appears to be inconclusive. Although there are varied opinions about the use and effectiveness of tax incentives, they remain an integral part of the tax policies of countries and it is expected that they will continue to be used globally.

\section{Use of and effectiveness of tax incentives in encouraging investment in renewable energy and energy efficiency in South Africa} Tax instruments available in South Africa

The South African government seems to prefer the use of tax incentives, rather than disincentives, to promote EE and RE. This is in line with what the literature suggested about developing countries generally avoiding tax disincentives when promoting environmentally friendly behaviour. The normal tax incentives available in South Africa (at the time of completion of the questionnaires) that can promote EE, RE or the R\&D of EE or RE technologies, are provided in Table 1. References to sections are to sections in the Income Tax Act No. 58 of 1962 (Republic of South Africa 1962).

Section 12B has been subsequently amended to grant a $100 \%$ allowance in the first year, but only in respect of small scale embedded solar photovoltaic RE with a generation capacity of less than $1 \mathrm{MW}$, instead of the three-year period for other 
TABLE 1: Energy efficiency or renewable energy tax incentives in South Africa.

\begin{tabular}{|c|c|c|}
\hline Description & Details & Section \\
\hline $\begin{array}{l}\text { Accelerated } \\
\text { depreciation } \\
\text { allowance (RE) }\end{array}$ & $\begin{array}{l}\text { In respect of assets brought into use for the } \\
\text { first time and solely for the production of } \\
\text { renewable electricity. The allowance is based } \\
\text { on the cost of the assets and } 50 \%, 30 \% \text { and } \\
20 \% \text { is granted in each of the first three years } \\
\text { of use, respectively. }\end{array}$ & $12 \mathrm{~B}(1)(\mathrm{h})$ \\
\hline $\begin{array}{l}\text { Energy savings } \\
\text { allowance (EE) }\end{array}$ & $\begin{array}{l}\text { Notional allowance for taxpayers that carry on } \\
\text { a trade and that implement EE projects that } \\
\text { successfully achieve energy savings. The } \\
\text { allowance is calculated as } 45 \text { cents per kilowatt } \\
\text { hour (kWh), or equivalent, of energy savings } \\
\text { achieved during the year of assessment, made } \\
\text { against a baseline measured at the beginning } \\
\text { of the year. Independent, registered and } \\
\text { accredited professionals need to measure and } \\
\text { verify the value of the energy savings and the } \\
\text { allowance is not granted if a concurrent EE } \\
\text { savings benefit is received from government or } \\
\text { a semi-government agency. }\end{array}$ & $12 \mathrm{~L}$ \\
\hline $\begin{array}{l}\text { Industrial policy } \\
\text { project (IPP) } \\
\text { allowance (EE) }\end{array}$ & $\begin{array}{l}\text { Industrial policy projects that use improved EE } \\
\text { and cleaner production technology, inter alia, } \\
\text { are entitled to an allowance of } 35 \%-100 \% \text { of } \\
\text { the cost of new and unused manufacturing } \\
\text { assets used in the project. }\end{array}$ & 121 \\
\hline $\begin{array}{l}\text { Exemption of } \\
\text { proceeds (RE/EE) }\end{array}$ & $\begin{array}{l}\text { When certified emission reductions from } \\
\text { approved clean development mechanism } \\
\text { (CDM) projects, registered before } 31 \text { December } \\
2020 \text {, are disposed of, the proceeds are } \\
\text { exempt. CDM projects could include RE or EE } \\
\text { projects. }\end{array}$ & $12 \mathrm{~K}$ \\
\hline $\begin{array}{l}\text { R\&D allowance } \\
\text { (RE/EE) }\end{array}$ & $\begin{array}{l}\text { A } 150 \% \text { allowance in respect of expenditure } \\
\text { incurred directly and solely on approved R\&D } \\
\text { activities undertaken in South Africa. The } \\
\text { expenditure must be incurred in the } \\
\text { production of income, in carrying on any trade. } \\
\text { The allowance also extends to pre-trade } \\
\text { expenditure incurred in respect of approved } \\
\text { R\&D activities. }\end{array}$ & $11 \mathrm{D} ; 11 \mathrm{~A}$ \\
\hline $\begin{array}{l}\text { Accelerated } \\
\text { depreciation } \\
\text { allowance for } \\
\text { R\&D (RE/EE) }\end{array}$ & $\begin{array}{l}\text { In respect of new and unused R\&D machinery } \\
\text { or plant brought into use for the first time. The } \\
\text { allowance is based on the cost of the assets } \\
\text { and } 50 \%, 30 \% \text { and } 20 \% \text { is granted in each of } \\
\text { the first three years of use, respectively. }\end{array}$ & $12 \mathrm{C}(1)(\mathrm{gA})$ \\
\hline $\begin{array}{l}\text { Depreciation } \\
\text { allowance for R\&D } \\
\text { buildings (RE/EE) }\end{array}$ & $\begin{array}{l}\text { The cost of a building used for R\&D is allowed } \\
\text { in equal portions over a period of } 20 \text { years. }\end{array}$ & $13(1)(b)$ \\
\hline
\end{tabular}

$\mathrm{CDM}$, clean development mechanism; $\mathrm{kWh}$, kilowatt hour; $\mathrm{RE}$, renewable energy; $\mathrm{EE}$, energy efficiency; IPP, industrial policy project; R\&D, research and development.

TABLE 2: Respondents that utilise the available tax incentives.

\begin{tabular}{lcc}
\hline Incentive & $\begin{array}{c}\text { Have claimed the } \\
\text { allowance already (\%) }\end{array}$ & $\begin{array}{c}\text { Will claim the allowance in } \\
\text { future (\%) }\end{array}$ \\
\hline Section 12L & 25 & 31 \\
Section 12B & 30 & 20 \\
R\&D allowances & 40 & 20 \\
Section 12K & N/A & N/A \\
Section 12I & 33 & 33 \\
\hline
\end{tabular}

$R \& D$, research and development

TABLE 3: Importance of availability of tax incentives.

Not important at all Only slightly important Fairly important Very important
$44 \%$ $19 \%$ $38 \%$

RE generators. This is effective for years of assessment commencing on or after 01 January 2016 (Republic of South Africa 2015b). Section 12L has subsequently been amended and the benefit increased from 45 cents per kWh to 95 cents per $\mathrm{kWh}$. This is deemed to come into operation for years of assessment commencing on or after 01 March 2015 (Republic of South Africa 2015b).

The only tax disincentives applied in South Africa that could have an impact on EE or RE is an environmental levy of 3.5 cents per $\mathrm{kWh}$ that is levied on electricity generated from non-renewable sources and an environmental levy of
400 cents per incandescent light bulb sold, which is either manufactured in or imported into the Republic of South Africa (Republic of South Africa 1964). The environmental levy was increased to 600 cents per electrical filament lamp with effect from 1 April 2016. A carbon tax is, however, being considered by the South African government. A draft Carbon Tax Bill was published in November 2015 and a revised version (considering public comments received) will be published for public consultation by mid-2017 (Republic of South Africa 2016a, 2017a). The proposed tax and its date of implementation will be considered further in Parliament later in 2017 (Republic of South Africa 2017b). Responses from industries to the proposed carbon tax have varied 'from cautious acceptance to clear rejection', with the main objection being that the tax will limit economic growth and impact negatively on job creation (Barnard 2016). This is the same reason that the literature suggested why developing countries tend to avoid environmental tax disincentives.

Since the South African government mainly uses tax incentives rather than disincentives, this study continues to explore the effectiveness of the available tax incentives in successfully inducing investment in RE and EE projects by large South African businesses.

\section{Findings from questionnaires: the use of available tax incentives by businesses}

All of the respondents (100\%) indicated that they either have completed EE projects or that they are in the process of implementing EE measures, while the majority (63\%) are already generating their own renewable electricity to some extent. The majority (63\%) of the respondents are also performing R\&D activities relating to EE or RE. None of the respondents have any CDM projects underway, although some indicated that they will establish such projects in the future. Although the majority of the respondents have EE, $\mathrm{RE}$ and/or R\&D (relating to EE or RE) projects, when asked whether or not the relevant tax incentives are utilised by them, not all of these respondents have actually claimed the incentives or are planning to claim them in the future. There are various potential reasons for this, which warrant further investigation. Table 2 summarises the responses of those respondents that have indicated that they either have a completed EE, RE, R\&D (relating to EE and/or RE), $\mathrm{CDM}$ or IPP project (as applicable), or are in the process of establishing such a project. Responses presented include those that have already claimed the relevant tax incentives and those that are planning to claim the incentives in the future.

\section{Findings from questionnaires: the importance of tax incentives in decision making}

A non-significant majority of the respondents (63\%) indicated that the availability of tax incentives was either not important at all or only slightly important to them when deciding whether or not to implement EE or RE measures, as set out in Table 3. The respondents, however, have varied opinions, 
TABLE 4: Factors that play a role when deciding to implement energy efficiency or renewable energy measures.

\begin{tabular}{lc}
\hline Variable & $\begin{array}{c}\text { Respondents that } \\
\text { agreed (\%) }\end{array}$ \\
\hline To save or conserve electricity & 94 \\
It will help reduce the business's carbon footprint & 81 \\
It will alleviate the strain on the electricity supply in South Africa & 75 \\
It will result in cost savings for the business & 75 \\
To increase the business's electricity independence & 56 \\
It will help reduce the country's overall emissions & 44 \\
$\begin{array}{l}\text { There are tax incentives available which the business could } \\
\text { apply for }\end{array}$ & 31 \\
$\begin{array}{l}\text { There are non-tax government incentives (financial or } \\
\text { non-financial) which the business could apply for }\end{array}$ & 19 \\
$\begin{array}{l}\text { There are government disincentives or penalties (in the form of } \\
\text { taxes, levies or otherwise) that discourage businesses from not } \\
\text { being energy efficient or using renewable energy }\end{array}$ & 13 \\
\hline \begin{tabular}{l} 
Other \\
\hline
\end{tabular} & - \\
\hline
\end{tabular}

TABLE 5: Order of importance of factors that potentially play a role in decisions.

\begin{tabular}{lc}
\hline Variable & Median \\
\hline It will result in cost savings for the business & 9 \\
\hline To save or conserve electricity & 7 \\
It will help reduce the business's carbon footprint & 6 \\
It will alleviate the strain on the electricity supply in South Africa & 5 \\
\hline To increase the business's electricity independence & 5 \\
\hline $\begin{array}{l}\text { There are tax incentives available which the business could apply for } \\
\text { It will help reduce the country's overall emissions }\end{array}$ & 5 \\
$\begin{array}{l}\text { There are non-tax government incentives (financial or non-financial) } \\
\text { which the business could apply for }\end{array}$ & 4 \\
$\begin{array}{l}\text { There are government disincentives or penalties (in the form of taxes, } \\
\text { levies or otherwise) that discourage businesses from not being energy } \\
\text { efficient or using renewable energy }\end{array}$ & 2 \\
\hline
\end{tabular}

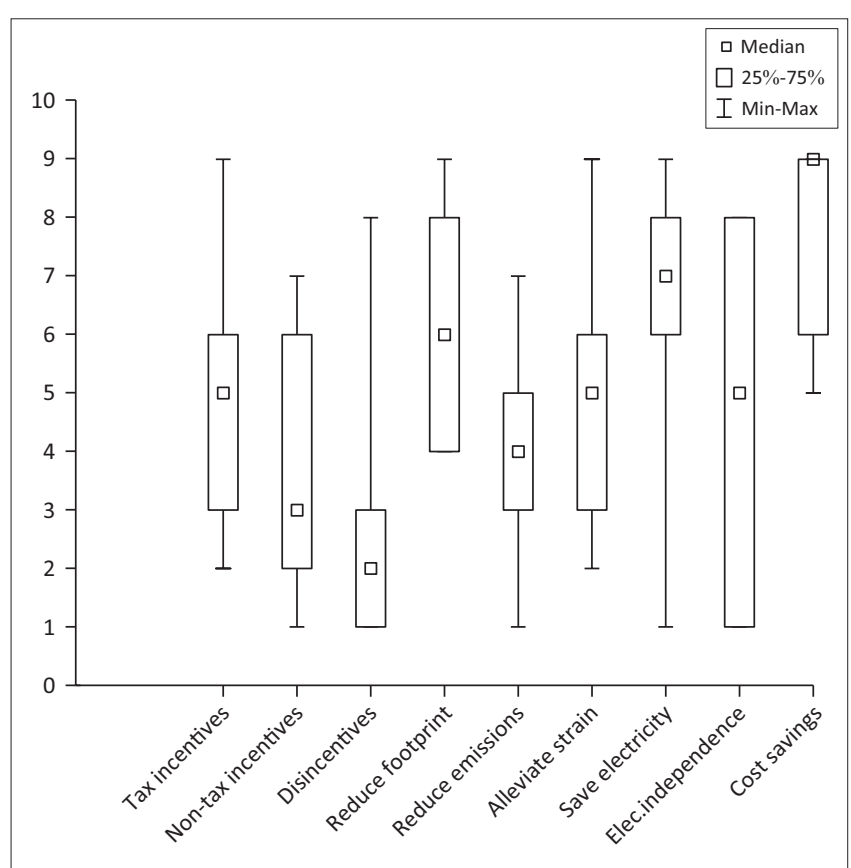

FIGURE 1: Statistical presentation of ranks of factors.

since $38 \%$ of them indicated that it was actually fairly important to them. To make comparisons, 'not important at all' and 'only slightly important' were grouped together (as a 'no') and compared with the grouping of 'fairly important' and 'very important' (a 'yes'). In addition, all of the respondents indicated that they would still have invested in $\mathrm{EE}$ or RE, even if there were no tax incentives or no government incentives available at all. This highlights the fact that, although the availability of tax incentives is considered important to some businesses, non-tax factors seem to drive investment decisions regarding RE and/or EE. The next section explores which factors are regarded as the most important to businesses when they consider investment in RE and/or EE projects.

\section{Findings from questionnaires: factors that drive decision making}

The top influencing factors that play a role in the decision making process of businesses regarding the implementation of EE or RE measures, as indicated by a statistically significant proportion of respondents, are to save or conserve electricity, the fact that it will help reduce a business' carbon footprint, that it will alleviate the strain on the electricity supply in South Africa and the fact that it will result in cost savings for the business, as indicated in Table 4 . Only 31\% of the respondents indicated that the availability of tax incentives play a role in the decision making process. The top four influencing factors (in terms of the number of respondents that selected them) were compared using Cochrane's test for nominal data (Yes/No answers). Cochrane's test statistics value is $\mathrm{Q}=3$ with degrees of freedom $(\mathrm{df})=3$ and $p$-value $=$ 0.392 , which is $>0.05$, so these chosen influencing variables do not differ significantly.

Next, considering the ranking of these variables, a clearer picture emerges. The possible influencing factors were ranked in order of importance by the respondents. A value of ' 9 ' was attributed to the most important aspect for businesses, while ' 1 ' represented the least important aspect. The median was then calculated for each factor (refer to Table 5), to determine the factor with the highest preference. It was clear that five respondents did not change the given order, when asked to list the nine factors in order of importance. Since these answers most likely do not represent the true order of importance for these respondents, these five were excluded from the calculation of the medians. The top factor influencing business decisions regarding EE or RE is cost savings, followed by saving electricity and reducing a business' carbon footprint, as indicated in Table 5. Once again, the availability of tax incentives was only moderately important, based on a median of ' 5 '. Using Friedman's test for ordinal data (where Friedman's test Chi square statistic $=$ 29.92 , df $=8$ and $p=0.0002$, which is $<0.05$ ), it could be determined that these nine medians in Table 5 differ significantly.

Using a Friedman-test in Figure 1, it is clear that the values attributed to 'cost savings' by respondents ranged from ' 5 ' to ' 9 ' (on a scale of ' 1 ' to ' 9 '), with the distribution significantly skewed to the top (it has a median of ' 9 '), that is to say, the majority of the respondents gave it the highest possible rating of ' 9 ' (the most important aspect). The results of 'tax incentives' (given a median of ' 5 ') vary and range from some respondents giving it a very low ' 2 ' to others giving it the highest possible score of ' 9 '. 
Based on the results in Tables 4 and 5, it is clear that, even though the availability of tax incentives plays a role in decision making, other non-tax factors appear to drive businesses' RE and/or EE investment decisions.

\section{Findings from questionnaires: effectiveness of tax incentives in South Africa}

A large majority (76\%) of respondent South African companies indicated that they do not perceive the currently available tax incentives to be effective in changing behaviour and stimulating investment in RE or EE, or that they only regard them as slightly effective, as summarised in Table 6. Responses varied from 'not effective at all' to 'fairly effective', but none of the respondents regard the available tax incentives as very effective. A statistically significant proportion of respondents (76\%) disagreed (either strongly or slightly) that the available tax incentives for EE and RE in South Africa are sufficiently motivating to induce a change in businesses' environmental behaviour, as set out in Table 7 .

The responses summarised in Table 7 indicate the following: only $44 \%$ of respondents agree (either slightly or strongly) that it is clear how to apply for the available tax incentives and a statistically significant proportion of respondents $(75 \%)$ agree (either slightly or strongly) that the South African government needs to reduce the burden of complying with the requirements of Section 12L and simplify the process of claiming under that section. It should be noted that only $56 \%$ of the companies that either have completed EE projects or such projects underway, have already claimed a Section 12L allowance or are planning to claim it in the future (Table 2). The reasons for this warrant further investigation, but a possible reason could be that the meeting criterion for Section $12 \mathrm{~L}$ is perceived to be too onerous, complicated and costly. Before an entity can claim this allowance, it needs an accredited professional to measure its energy savings. The expected benefit of claiming the tax allowance should therefore exceed the expenditure incurred in the measurement and verification process by the accredited professional before a company would be likely to utilise this incentive (Thetard 2013).

TABLE 6: Perceived effectiveness of available tax incentives relating to energy efficiency or renewable energy in South Africa.

\begin{tabular}{lccc}
\hline Not effective at all & Only slightly effective & Fairly effective & Very effective \\
\hline $13 \%$ & $63 \%$ & $25 \%$ & - \\
\hline
\end{tabular}

TABLE 7: Claiming the available tax incentives in South Africa.

\begin{tabular}{|c|c|c|c|c|c|}
\hline Variable & $\begin{array}{c}\text { Strongly } \\
\text { disagree } \\
(\%)\end{array}$ & $\begin{array}{c}\text { Disagree } \\
\text { slightly (\%) }\end{array}$ & $\begin{array}{c}\text { Agree } \\
\text { slightly (\%) }\end{array}$ & $\begin{array}{c}\text { Strongly } \\
\text { agree }(\%)\end{array}$ & $\begin{array}{c}\text { Not aware of } \\
\text { the Section } 12 \mathrm{~L} \\
\text { requirements } \\
(\%)\end{array}$ \\
\hline $\begin{array}{l}\text { Available tax } \\
\text { incentives are } \\
\text { sufficiently } \\
\text { motivating to } \\
\text { change behaviour }\end{array}$ & 38 & 38 & 19 & 6 & N/A \\
\hline $\begin{array}{l}\text { It is clear how to } \\
\text { apply for the } \\
\text { available tax } \\
\text { incentives }\end{array}$ & 25 & 31 & 31 & 13 & $\mathrm{~N} / \mathrm{A}$ \\
\hline $\begin{array}{l}\text { Less onerous } \\
\text { requirements of } \\
\text { Section } 12 L \text { is } \\
\text { needed }\end{array}$ & 6 & 13 & 19 & 56 & 6 \\
\hline
\end{tabular}

It is recommended that the process to claim the available tax incentives is simplified, the requirements are reduced or simplified and the financial benefit increased or more incentives made available to encourage businesses to implement RE and/or EE projects and to claim the Section 12L allowance, where applicable.

South African businesses appear to favour tax and other financial incentives over non-financial incentives and disincentives, to encourage EE and RE. Table 8 indicates that a statistically significant proportion of respondents (82\%) agree (either slightly or strongly) that the South African government needs to offer more tax incentives and $88 \%$ agree (either slightly or strongly) that more financial incentives, such as tax incentives, subsidies, grants or purchasing rebates, are needed to encourage EE and/or RE in businesses. In order to make comparisons, 'strongly disagree' and 'disagree slightly' were grouped together (as a 'no') and compared with the grouping of 'agree slightly' and 'strongly agree' (a 'yes'). A statistically significant proportion of respondents $(69 \%)$ feel that the number of disincentives should not be increased.

The mean was calculated for each of the statements contained in Table 8 , using the following scale: $1=$ strongly disagree; 2 =disagree slightly; $3=$ agree slightly; $4=$ strongly agree. Using a non-parametric repeated measures analysis of variance test, i.e. a Friedman's test (where Friedman's test Chi square statistic $=20.13, \mathrm{df}=3$ and $p=0.00016)$, it is clear that the results of the first two statements (government should offer more tax incentives and more financial incentives) differ statistically significantly from the results of the second two statements (government should offer more non-financial incentives and more disincentives). This is illustrated in Figure 2, using lettering from a Bonferroni multiple comparisons procedure. Financial incentives (including tax incentives) are clearly preferred to non-financial incentives and disincentives.

\section{Conclusion: The South African situation}

The findings from the questionnaires suggest that not all businesses that potentially qualify for the existing tax incentives aimed at promoting EE and RE, utilise the tax incentives. The reasons for this warrant further investigation. The respondents have varied opinions about

TABLE 8: Preference of government measures to encourage energy efficiency or renewable energy in South Africa.

\begin{tabular}{lcccc}
\hline Variable & $\begin{array}{c}\text { Strongly } \\
\text { disagree (\%) }\end{array}$ & $\begin{array}{c}\text { Disagree } \\
\text { slightly (\%) }\end{array}$ & $\begin{array}{c}\text { Agree } \\
\text { slightly (\%) }\end{array}$ & $\begin{array}{c}\text { Strongly } \\
\text { agree (\%) }\end{array}$ \\
\hline $\begin{array}{l}\text { Offer more tax } \\
\text { incentives }\end{array}$ & 6 & 13 & 19 & 63 \\
$\begin{array}{l}\text { Offer more } \\
\text { financial } \\
\text { incentives }\end{array}$ & 6 & 6 & 25 & 63 \\
$\begin{array}{l}\text { Offer more } \\
\text { non-financial } \\
\text { incentives }\end{array}$ & 27 & 20 & 40 & 13 \\
$\begin{array}{l}\text { Offer more } \\
\text { disincentives }\end{array}$ & 44 & 25 & 25 & 6 \\
$\begin{array}{l}\dagger, \text { One respondent that answered 'strongly agree' was excluded from the analysis based on } \\
\text { a misunderstanding of the question. Consequently, the percentages were adjusted } \\
\text { accordingly. }\end{array}$ &
\end{tabular}




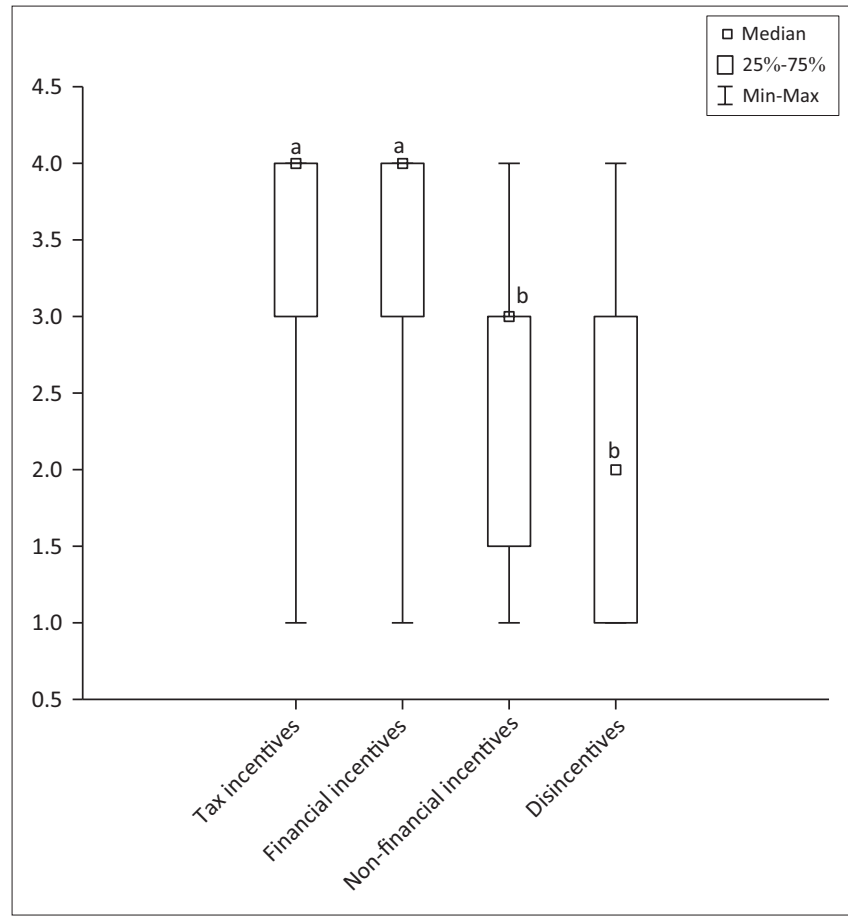

FIGURE 2: Statistical comparison of government measures, indicating differences.

the importance of tax incentives in decision making, with responses ranging from 'not important at all' to 'fairly important'. The top influencing factors that drive decision making regarding the implementation of $\mathrm{EE}$ and/or RE measures (as indicated by a statistically significant proportion of the respondents), are to conserve electricity, the fact that it will help businesses reduce their carbon footprint, that it will alleviate the strain on the electricity supply and that it will result in cost savings for the business. The top factor influencing business decisions regarding EE and RE (when respondents were asked to rank a number of factors in order of importance) is cost savings, followed by saving electricity and reducing a business' carbon footprint. Although tax incentives play a role in the decision making of South African businesses, many non-tax factors drive investment decisions, similar to what the literature suggest about the global situation.

A statistically significant proportion of respondents indicated that the current tax incentives for EE and RE in South Africa are not effective (or only slightly effective) in changing behaviour and stimulating investment in RE or EE and are not sufficiently motivating to induce a change in environmental behaviour. In addition, they feel that the government should reduce the burden of complying with the requirements of Section 12L (the EE allowance).

\section{Conclusion}

The objective of the study was to determine the role that the currently available tax incentives play in the decision making of South African businesses regarding investment in RE or EE projects. A literature review was conducted to determine the role of tax incentives globally, while questionnaires were distributed to determine the role in South Africa.

The literature review revealed that tax incentives could effectively address environmental challenges and change consumer behaviour, although tax incentives are generally more effective in combination with other policy instruments. Some argue, however, that tax incentives are ineffective, because non-tax considerations have a larger impact on investment decisions and many factors besides tax instruments drive investment decisions. Although there are varied opinions about the use and effectiveness of tax incentives, they remain an integral part of countries' tax policies and it is expected that they will continue to be used globally.

Findings from the questionnaires highlighted the fact that, although tax incentives do play a role in decision making, various other non-tax factors drive South African businesses' decisions to invest in EE and/or RE projects. These businesses also do not perceive the available tax incentives as effective, nor do they regard them as sufficiently motivating for businesses to change their environmental behaviour. However, improving the available RE and EE tax incentives in South Africa, might result in more businesses considering the implementation of RE or EE projects.

South African businesses feel that the government should reduce the burden of complying with the requirements of Section 12L (the EE allowance). It is therefore recommended that the process to claim the currently available RE or EE tax incentives is simplified, the requirements are reduced or simplified and the financial benefit increased or more incentives made available to encourage businesses to change their environmental behaviour. Alternatively, the implementation of the proposed carbon tax (a tax disincentive) in South Africa could play a role in altering businesses' environmental behaviour.

\section{Acknowledgements Competing interests}

The author declares that there were no conflicts of interest during the writing of this article.

\section{References}

Anjum, N., 2008, 'Prospects of green-taxes in developing countries', Business and Finance Review, n.p., 28 April.

Ashiabor, H., 2005, 'Fostering the development of renewable energy through green taxes and other instruments', Bulletin for International Taxation 59(7), 295-305.

Barnard, M., 2016, Carbon tax as proposed environmental fiscal reform measure in South Africa, viewed 24 July 2017, from http://www.litnet.co.za/carbon-taxproposed-environmental-fiscal-reform-measure-south-africa/

Bennet, P. \& Moore, N., 1981, 'Consumer preferences for alternative energy conservation policies: A trade-off analysis', Journal of Consumer Research 8(3), 313-321. https://doi.org/10.1086/208870

Bierbaum, R. \& Friedman, R.M., 1992, 'The road to reduced carbon emissions', Issues in Science and Technology 8(2), 58-65.

Bird, R.M., 2008, Tax challenges facing developing countries, Rotman Institute for International Business Working Paper Series IIB Paper no. 9., University of Toronto Joseph L. Roman School of Management, Toronto. 
Braathen, N.A., 2007, 'Instrument mixes for environmental policy: How many stones should be used to kill a bird?', International Review of Environmental and Resource Economics 1(2), 185-235. https://doi.org/10.1561/101.00000005

Calitz, E., Wallace, S. \& Burrows, L., 2013, The impact of tax incentives to stimulate investment in South Africa, Stellenbosch Economic Working Papers 19/13, University of Stellenbosch, Stellenbosch, South Africa.

Cargill, J.G., 2011, 'The role of market-based instruments that use existing markets to promote energy efficiency in South African industry', Master thesis, University of Cape Town, Cape Town, South Africa.

Chanel, G., 2012, 'Green taxes on brown energy: Governments target fossil fuel use', EY's T Magazine, 28 May, viewed 28 January 2014, from http://taxinsights.ey. com/archive/archive-articles/green-taxes-on-brown-energy-governments-targetfossil-fuel-use.aspx

Cohen, B. \& Winkler, H., 2014, 'Greenhouse gas emissions from shale gas and coal for electricity generation in South Africa', South African Journal of Science 110(3/4), 31-35.

Centre for Resource Solutions (CRS), 2005, International tax incentives for renewable energy: Lessons for public policy (draft report), CRS, San Francisco, CA.

Deloitte, 2010, Alternative thinking 2011: A look at 10 of the top issues and trends in renewable energy, Deloitte, London, UK.

Du Plooy, J.L., 2012, 'A study of a "feebate" policy to reduce $\mathrm{CO}_{2}$ emissions in the South African automotive industry,' Master thesis, University of Stellenbosch, Stellenbosch, South Africa.

Easson, A. \& Zolt, E.M., 2002, Tax incentives, Working Paper, World Bank Institute, Washington, DC, pp. 1-35.

Economy, E., 2006, Environmental governance: The emerging economic dimension Environmental Politics 15(2), 171-189. https://doi.org/10.1080/09644010600 562310

Eskom, 2016, Integrated report, 31 March, viewed 24 July 2017, from http://www. eskom.co.za/IR2016/Documents/Eskom_integrated_report_2016.pdf

Geller, H., Harrington, P., Rosenfeld, A.H., Tanishima, S. \& Unander, F., 2006, 'Policies for increasing energy efficiency: Thirty years of experience in OECD countries', Energy Policy 34(5), 556-573. https://doi.org/10.1016/j.enpol.2005.11.010

Gouchoe, S., Everette, V. \& Heynes, R., 2002, Case studies on the effectiveness of state financial incentives for renewable energy, National Renewable Energy Laboratory, Golden, CO.

Hassett, K.A. \& Metcalf, G.E., 1995, 'Energy tax credits and residential conservation investment: Evidence from panel data', Journal of Public Economics 57(1995), 201-217. https://doi.org/10.1016/0047-2727(94)01452-T

Institute of Directors Southern Africa (IOD), 2009, The King Report on corporate governance for South Africa, Institute of Directors in Southern Africa, Johannesburg, South Africa.

IPP Projects, n.d., Independent power producer procurement programme, viewed 27 July 2017, from https://www.ipp-projects.co.za/

JSE (JSE Limited), 2013, Guidance letter: Integrated reporting, 27 June, viewed 30 September 2015, from https://www.jse.co.za/content/JSERulesPoliciesand Regulationltems/JSE\%20Listings\%20Requirements.pdf

JSE (JSE Limited), 2014a, 2014 SRI Index constituents, 27 November, viewed 30 September 2015, from https://www.jse.co.za/Content/JSEIndexConstituentsand WeightingsItems/2014SRIIndexConstituentsbestperformers.pdf

JSE (JSE Limited), 2014b, SRI index background and criteria 2014, viewed 30 September 2015, from https://www.jse.co.za/Content/JSERulesPoliciesandRegulationltems/ Background $\% 20$ and $\% 20$ Criteria $\% 202014$.pdf

KPMG, 2013a, Taxes and incentives for renewable energy, viewed 17 April 2014, from https://assets.kpmg.com/content/dam/kpmg/pdf/2013/11/Taxes-andIncentives-for-Renewable-Energy-2013-0-201310.pdf

KPMG, 2013b, The KPMG green tax index 2013, viewed 17 April 2014, from https:// assets.kpmg.com/content/dam/kpmg/pdf/2013/08/kpmg-green-tax-index-2013. pdf

Lomas, U., 2012, 'Dutch investment tax boosts renewable energy', Tax News, 23 July, viewed 17 April 2014, from http://www.tax-news.com/news/Dutch_Investment Tax_Boosts_Renewable_Energy_56469.htm

Markandya, A., Ortiz, R.A., Mudgal, S. \& Tinetti, B., 2009, 'Analysis of tax incentives for energy-efficient durables in the EU', Energy Policy 37(2009), 5662-5674. https:// doi.org/10.1016/j.enpol.2009.08.031

Mychajluk, M., 2015, e-mail, 01 June, MariaMy@jse.co.za

Nathan-MSI Group, 2004, Effectiveness and economic impact of tax incentives in the SADC region, viewed 17 April 2014, from http://pdf.usaid.gov/pdf docs/ Pnacy929.pdf

Niesing, G., 2012, 'Assessing the barriers companies face towards the implementation of corporate energy efficiency strategies', Master thesis, North-West University, Potchefstroom, South Africa.

Nortje, D., 2009, 'A literature study of renewable energy tax incentives', Master thesis, University of Pretoria, Pretoria, South Africa.

Nteo, L.D., 2012, 'Role of market based instruments in transitioning to a low carbon economy: Experiences from BRICS countries and lessons for South Africa', Master thesis, Gordon Institute of Business Science University of Pretoria, Pretoria, South Africa.
PBL (PBL Netherlands Environmental Assessment Agency), 2016, Trends in global CO emissions 2016 report, viewed 24 July 2917, from http://edgar.jrc.ec.europa.eu/ news_docs/jrc-2016-trends-in-global-co2-emissions-2016-report-103425.pdf

PricewaterhouseCoopers, 2010, Appetite for change: Global business perspectives on tax and regulation for a low carbon economy, viewed 17 April 2014, from https:// www.pwc.co.uk/assets/pdf/appetite-for-change.pdf

Republic of South Africa, 1962, Income Tax Act 58 of 1962, Government Printer, Pretoria, South Africa.

Republic of South Africa, 1964, Customs and Excise Act 91 of 1964, Government Printer, Pretoria, South Africa.

Republic of South Africa, 2015a, South Africa yearbook 2014/15, Government Printer, Pretoria, South Africa.

Republic of South Africa, 2015b, Explanatory memorandum on the taxation laws amendment bill, 2015, Government Printer, Pretoria, South Africa.

Republic of South Africa, 2016a, 2016 Budget review, viewed 24 November 2016, from http://www.treasury.gov.za/documents/national\%20budget/2016/review/ chapter\%204.pdf

Republic of South Africa, Department of Energy, 2010, Integrated resource plan for electricity 2010-2030, viewed 26 July 2017 from http://www.energy.gov.za/IRP/ irp\%20files/IRP2010_2030_Final_Report_20110325.pdf

Republic of South Africa, Department of Energy, 2016c, Draft post-2015 national energy efficiency strategy, Government Gazette no. 40515, 23 December.

Republic of South Africa, Department: Environmental Affairs, 2016b, South Africa signs Paris agreement on climate change in New York, viewed 24 July 2017, from https://www.environment.gov.za/mediarelease/southafricasignsparis agreementonclimate

Republic of South Africa, Department of Minerals and Energy, 2004, White paper on renewable energy November 2003, Government Gazette no. 26169, 14 May, Government Printer, Pretoria, South Africa.

Republic of South Africa, National Treasury, 2006, Draft policy paper: A framework for considering market-based instruments to support environmental fiscal reform in South Africa, Government Printer, Pretoria, South Africa.

Republic of South Africa, National Treasury, 2013, Policy paper for public comment: Carbon tax policy paper: Reducing greenhouse gas emissions and facilitating the transition to a green economy, Government Printer, Pretoria, South Africa.

Republic of South Africa, National Treasury, 2017a, Budget review 2017, viewed 24 July 2017, from http://www.treasury.gov.za/documents/national\%20budget/2017/ review/FullBR.pdf

Republic of South Africa, National Treasury, 2017b, Minister Pravin Gordhan: 2017 Budget Speech, viewed 24 July 2017, from http://www.gov.za/SPEECHES/ MINISTER-PRAVIN-GORDHAN-2017-BUDGET-SPEECH-22-FEB-2017-0000

Sawyer, A., 2005, 'Reflections on providing tax incentives for research and development: New Zealand at the cross roads', Journal of Australian Taxation 8(1), 111-149.

Thetard, S., 2013, Finally a tax rebate with the energy to change, viewed 06 May 2014 from http://energyefficiencycourses.co.za/category/blog/

United Nations Industrial Development Organisation (UNIDO), 2009, Scaling up renewable energy in Africa: 12th ordinary session of Heads of State and Governments of the African Union, Vienna, Austria.

Van Schalkwyk, S.G., 2012, An international comparison of environmental tax with an emphasis on South Africa, Master thesis, University of Pretoria, Pretoria, South Africa.

Winkler, H., 2005, 'Renewable energy policy in South Africa: Policy options for renewable electricity', Energy Policy 33(1), 27-38. https://doi.org/10.1016/ S0301-4215(03)00195-2

Winkler, H., 2007, 'Energy policies for sustainable development in South Africa', Energy for Sustainable Development XI(1), 26-34.

Wiser, R., Hamrin, J. \& Wingate, M., 2002, Renewable energy policy options for China A comparison of renewable portfolio standards, feed-in tariffs, and tendering
policies, Center for Resources Solutions, viewed 31 January 2018, from https:// policies, Center for Resources Solutions, viewed 31 January 2018, from https://
resource-solutions.org/wp-content/uploads/2015/08/IntPolicy-Feed-in resource-solution
LawsandRPS.pdf

World Energy Council, 2010, Pursuing sustainability: 2010 Assessment of country energy and climate policies, viewed 17 April 2014, from https://www.worldenergy. onergy and climate policies, viewed 17 April 2014, from https://www.worldenergy. org/wp-content/uploads/2012/10/PU

World Resources Institute (WRI), 2008, 'Renewable energy tax credits', The Bottom line on..., Issue 4, WRI, Washington, DC.

Yuan, M., Tuladhar, S., Bernstein, P. \& Lane, L., 2011, 'Policy effectiveness in energy conservation and emission reduction', The Energy Journal 32(special issue 1), 153-172.

Zee, H.H., Stotsky, J.G. \& Ley, E., 2002, 'Tax incentives for business investment: A primer for policy makers in developing countries', World Development 30(9), 1497-1516. https://doi.org/10.1016/S0305-750X(02)00050-5

Zhou, N., Levine, M.D. \& Price, L., 2010, 'Overview of current energy-efficiency policies in China', Energy Policy 38(11), 6439-6452. https://doi.org/10.1016/j.enpol. 2009.08.015

Zhou, Y., Wang, L. \& Mccalley, J.D., 2011, 'Designing effective and efficient incentive policies for renewable energy in generation expansion planning', Applied Energy 88(2011), 2201-2209. https://doi.org/10.1016/j.apenergy.2010.12.022 


\section{Appendix 1}

TABLE 1-A1: The following table sets out the sectors in which the respondents of the questionnaire operate.

\begin{tabular}{|c|c|c|}
\hline $\begin{array}{l}\text { Company listed on JSE } \\
\text { Top } 40 \text { Index (listed } \\
\text { alphabetically) }\end{array}$ & $\begin{array}{l}\text { Respondent company } \\
\text { (if different from JSE } \\
\text { Top } 40 \text { company) }\end{array}$ & Sector \\
\hline Barclays Africa Group Ltd & ABSA Bank Ltd & Financial services \\
\hline Capitec Bank Holdings Ltd & - & Financial services \\
\hline Growthpoint Properties Ltd & - & Real estate \\
\hline Investec plc & Investec Ltd & Financial services \\
\hline Kumba Iron Ore Ltd & - & Basic resources \\
\hline Mediclinic International Ltd & Mediclinic Southern Africa & Health care \\
\hline Mondi plc & Mondi Ltd & Basic resources \\
\hline Mr Price Group Ltd & - & Retail \\
\hline Naspers Limited (Ltd) & $\begin{array}{l}\text { MultiChoice Group SA } \\
\text { (subsidiary of Naspers) }\end{array}$ & Media \\
\hline Nedbank Group Ltd & - & Financial services \\
\hline Netcare Ltd & - & Health care \\
\hline Remgro Ltd & - & $\begin{array}{l}\text { Industrial goods and } \\
\text { services }\end{array}$ \\
\hline Sasol Ltd & - & Oil and gas \\
\hline Shoprite Holdings Ltd & - & Retail \\
\hline Standard Bank Group Ltd & - & Financial services \\
\hline Woolworths Holdings Ltd & - & Retail \\
\hline
\end{tabular}

JSE, Johannesburg Stock Exchange. 